\title{
Primitive Accumulation and 'Progress' in Southeast Asia: The Diverse Legacies of a Common(s) Tragedy
}

\author{
John T. Sidel
}

\begin{abstract}
More than any other scholar, James C. Scott has drawn attention to the significance of what Marx termed 'primitive accumulation' in the historical transformation of the societies of Southeast Asia. Taking Scott's work as its point of departure, this article sketches the broad contours of primitive accumulation across the region from the mid-nineteenth century up through the early twentieth century. The article shows how primitive accumulation unfolded in different ways in different parts of Southeast Asia and suggests how the different modalities of primitive accumulation have continued to shape the trajectories and parameters of politics across the region to this day.
\end{abstract}

KEYWORDS: Southeast Asia, James C. Scott, primitive accumulation

\section{INTRODUCTION}

To one Has DONE more over the years to draw scholarly attention to the 1 immediate impact and long-term consequences of what Marx termed 'primitive accumulation' in Southeast Asia than James C. Scott, beginning with his early work on patron-client relations, continuing with his 1976 classic Moral Economy of the Peasant, and seen even in his most recent page-turner, The Art of Not Being Governed. While in these works (as elsewhere) Scott takes issue with many aspects of Marxism and tends to favour a Polanyian approach to 'the great transformation' of Southeast Asia, his account of rural dispossession in the region in the late colonial era clearly draws inspiration from Marx's notion of 'primitive accumulation'. As Scott argues in the introduction to The Moral Economy of the Peasant:

"Two major transformations during the colonial period in Southeast Asia served to undermine radically the pre-existing social insurance patterns and to violate the moral economy of the subsistence ethic. These were, first, the imposition of what Eric Wolf has called 'a particular cultural system, that of North Atlantic capitalism’ and, second, the related development of the modern state under a colonial aegis. The transformation of land and labor (that is, nature and human work) into commodities for sale had the

John T. Sidel, Department of Government and the Department of International Relations, London School of Economics and Political Science; j.t.sidel@lse.ac.uk 
most profound impact. Control of land increasingly passed out of the hands of villagers; cultivators progressively lost free usufruct rights and became tenants or agrarian wage laborers; the value of what was produced was increasingly gauged by the fluctuations of an impersonal market. In $a$ sense, what was happening in Southeast Asia was nothing more than a parochial recapitulation of what Marx had observed in Europe. 'But on the other hand, these new freedmen became sellers of themselves only after they had been robbed of all their own means of production and of all the guarantees of existence afforded by the old feudal arrangements. And the history of this, their expropriation, is written in the annals of mankind in letters of blood and fire." (Scott 1976: 7-8, emphasis added).

Over the past few decades, scholars have, however obliquely and un-self-consciously, followed Scott in acknowledging the importance of primitive accumulation by highlighting the lingering legacies of state and class formation on contemporary politics in Southeast Asia. Indeed, it is by now a commonplace to note the importance of 'colonial legacies' for determining the parameters of politics in countries ranging from Burma (now Myanmar) to Malaysia and the Philippines, and to use such 'colonial legacies' as the basis for cross-national comparative analysis within the region. But these exercises in comparative historical sociology have been almost exclusively ‘top-down' in approach and emphasis, focusing on the identities and interests of ruling classes and the institutional contexts within which domination, exploitation, and accumulation unfold across Southeast Asia today. ${ }^{1}$

This article, by contrast, takes as its starting point the varying experiences of primitive accumulation by the subaltern classes of the region. It will be shown that primitive accumulation in Southeast Asia unfolded under different circumstances in different parts of the region, and with differential impacts on and implications for those Southeast Asians who found themselves dispossessed and dislodged from direct access to the means of production, and who faced expropriation and the imposition of new forms of exploitation and domination under conditions of private property, wage labour, and the operations of a market economy. Focusing on the cases of Java, the Malay Peninsula, the Philippine archipelago, and the major river deltas of Mainland Southeast Asia, this essay suggests the possibilities for a new comparative historical sociology of working-class formation across the region, informed and inspired by the 'worm's-eye view' opened up by the work of Jim Scott. The diverging experiences of primitive accumulation among Southeast Asia's subaltern classes, it is argued, have in crucial ways shaped the variegated political trajectories of the diverse countries of the region for many decades, thus reaffirming Scott's call for an approach to the study of politics 'from below', paying close attention to moral

\footnotetext{
${ }^{1}$ For a noteworthy exception, see Hedman (2001).
} 
economies, peasant rebellions, and forms of contestation and resistance which otherwise remain hidden from view.

\section{Primitive Accumulation as Point of Departure}

Why should scholars working on the twenty-first century politics of urbanising, industrialising Southeast Asia direct their attention to 'primitive accumulation' in the rural areas of the region over the late nineteenth and early twentieth centuries? Up into the early centuries of the second millennium of the so-called Common Era, both the inland agrarian states and the port polities of Southeast Asia depended for their emergence, entrenchment, and endurance upon the capture of labour and produce from their hinterlands. However, the highly restricted nature of control over commodity flows and manpower made for attenuated and at times ephemeral forms of surplus extraction and state formation, with contestation and flux characterising politics across the region. Over the course of the early modern era (c.1350-1850), 'early globalisation' and the 'military revolution' combined to enable greater centralisation and consolidation of rule, especially in Mainland Southeast Asia, through the extension and intensification of domination and exploitation by 'exemplary centres' over their hinterlands (Lieberman 2003). Thus the very basis of political order in Southeast Asia can be traced back to processes of what we might term 'primitive political accumulation'. Arguably early post-independence 'nation-building' and 'national integration' can be understood as a more recent version of the same kind of transformation (Sidel 2012). Even today, we can appreciate the twin imperatives of surplus extraction and social control which face states as they 'see' their hinterlands from various Southeast Asian capitals.

But beyond successive instances of 'political accumulation', something arguably more important and irrevocable began to unfold across key regions of Southeast Asia over the course of the mid-late nineteenth century and the first decades of the twentieth century. Here, what Karl Polanyi termed 'the Great Transformation' and Barrington Moore, Jr. glossed as the 'commercialisation of agriculture' can also be understood in the language of Karl Marx as 'primitive accumulation'. This process of expropriation of the means of production was famously depicted by Marx (1977: 928) as having been "accomplished by means of the most merciless barbarianism, and under the stimulus of the most infamous, the most sordid, the most petty and the most odious of passions." However, beyond this moral condemnation, Marx also identified primitive accumulation as an historical necessity for the emergence and evolution of capitalism as a mode of production. For capitalist relations to reproduce themselves through the 'silent compulsion' of the market, a preceding phase of 'primitive accumulation' was required to commodify land and labour, and to create a 'reserve army' of 'surplus labour'. Such a 
process of dispossession required direct application of coercion and violence, reflecting

“...the pretensions of capital in its embryonic state, in its state of becoming, when it cannot yet use the sheer force of economic relations to secure its right to absorb a sufficient quantity of surplus labor, but must be aided by the power of the state....Centuries are required before the 'free' worker, owing to the greater development of the capitalist mode of production, makes a voluntary agreement, i.e. is compelled by social conditions to sell the whole of his active life." (Marx 1977: 382)

"The advance of capitalist production develops a working class which by education, tradition and habit looks upon the requirements of that mode of production as self-evident natural laws. The organization of the capitalist process of production, once it is fully developed, breaks down all resistance. The constant generation of a relative surplus population keeps the law of the supply and demand of labor, and therefore wages, within narrow limits which correspond to capital's valorization requirements. The silent compulsion of economic relations sets the seal on the domination of the capitalist over the worker. Direct extra-economic force is still of course used, but only in exceptional cases. In the ordinary run of things, the worker can be left to the 'natural laws of production,' i.e. it is possible to rely on his dependence on capital, which springs from the conditions of production themselves, and is guaranteed in perpetuity by them. It is otherwise during the historical genesis of capitalist production. The rising bourgeoisie needs the power of the state, and uses it to 'regulate' wages, i.e. to force them into the limits suitable to make a profit, to lengthen the working day, and to keep the worker himself at his normal level of dependence. This is an essential aspect of socalled primitive accumulation." (Marx 1977: 899-900)

Thus, the period of primitive accumulation was one which required active intervention and innovation through modern state structures and forms of what Foucault called discipline, through "the establishment of an explicit, coded and formally egalitarian juridical framework," and "the development and generalization of disciplinary mechanisms" - "tiny, everyday, physical mechanisms [of] micro-power" (Foucault 1977: 222). In other words, primitive accumulation in Marx's sense of the term was inherently wrapped up in the formation of modern states and in the making of other forms of modern disciplinary power.

For much of Southeast Asia, the most important phase of primitive accumulation unfolded over the course of the late nineteenth century and into the first decades of the twentieth century. Economic and social historians have chronicled these developments as part of the deepening integration of Southeast Asia into the world capitalist economy, and the elaboration and expansion of 'commodity chains' linking peasants through credit, marketing, and processing to the key 
port cities of the region and to global circuitries of commerce beyond. Since John Furnivall's (1939) tragi-comic account of The Fashioning of Leviathan, moreover, historians have also shown how this Great Transformation was enabled and impelled by the construction of the modern - typically colonial - state structures which could impose 'free trade', create and enforce new kinds of property rights, and oversee the making of 'market societies' across the region. Small wonder, as Furnivall (1948) noted, that there was such a close correspondence between areas of intensive 'direct' colonial rule on the one hand, and those zones of Southeast Asia where market forces were most fully developed. Thus we can date the onset of primitive accumulation in Southeast Asia to the end of the Java War and the imposition of the Cultivation System in 1830, the liberalisation of Philippine trade in the 1840s, the Second Anglo-Burmese War in 1852, the signing of the Bowring Treaty of 1855 in Siam, the consolidation of French rule in Cochinchina in the 1860s, and the extension of British and French rule to Upper Burma, the Malay States, Annam, and Tonkin in the 1870s and the 1880s. The processes of primitive accumulation unleashed during these decades expanded and accelerated through the first decades of the twentieth century, setting the stage for capitalist development in Southeast Asia in the post-war era of independence. While Southeast Asians had been producing goods for markets and participating in the world economy for centuries, it was only through primitive accumulation in the mid-late nineteenth and early twentieth centuries that the region was reordered along the lines of a 'market society', with increasingly densely populated core zones organised around intensively commercialised agricultural production.

But if primitive accumulation can be glossed in such broad-brush terms, how might it help us to understand patterns of politics in Southeast Asia - and to explain differences across the region - today? If primitive accumulation was 'of a piece' in Southeast Asia, if its outcome was inevitable, then its consequences would have been uniform across the region. However, scholars have highlighted the lasting legacies of differences in the ways in which primitive accumulation unfolded for the formation of classes and states in other parts of the world, most obviously Europe and Latin America (see for example: Aston and Philpin 1985; Mahoney 2001; Moore 1966; Paige 1997). Scholars of Southeast Asia have likewise stressed the enduring significance of the diverging patterns of assimilation and segregation experienced by the immigrant Chinese merchant communities who played such an important role in the accumulation of capital and the formation of capitalist classes across the region (see for example, Sidel 2008). In this sense, we already know that the modalities of primitive accumulation 'matter'.

As noted above, though, the work of James C. Scott has suggested a very different vantage point from which to evaluate the varying contexts, forms, and consequences of primitive accumulation across Southeast Asia. Here, whether we celebrate primitive accumulation as 'progress', condemn it as 'barbarism', or accept it as 'historical necessity', we might heed Scott's advice and his 
example. Looking not just 'from above' but 'from below', seeing not just like a state' but also like a peasant, we should not assume the inevitable triumph of the capitalist market and the seamless hegemony of capitalist classes. Instead, we should examine the dialectical significance of the myriad forms of Polanyian 'counter-movement' and Schweikian foot-dragging and resistance engendered by primitive accumulation. If primitive accumulation was necessary for the making of capitalist production relations, the formation of capitalist classes and working classes, and the construction of modern nation-states across Southeast Asia, then variations in the circumstances and processes of primitive accumulation in the region must be foundational and fundamental in many ways. Thus the pages below suggest how we might begin to explore this line of inquiry.

\section{Primitive Accumulation in Mainland River Deltas: Siam AND ITS TWO TWINs?}

An easy and obvious initial illustration of this kind of analysis is presented by the cases of the three major river deltas of Mainland Southeast Asia, where primitive accumulation began to unfold and accelerate in the latter half of the nineteenth century. In the Mekong, Chao Phraya, and Irrawaddy river deltas, this development arose and evolved through the dramatic growth of the rice trade, as the volume of rice exported increased by 500 per cent between the early $1860 \mathrm{~s}$ and the early 1900s. Facilitated by the imposition of 'free trade' in Siam under the Bowring Treaty of 1855 and the establishment of direct colonial rule under British and French auspices in Lower Burma and Cochinchina over the 1850s and 1860s, this boom in the rice trade stimulated a massive wave of land clearance and settlement. If historians estimate that the total area devoted to rice cultivation in Mainland Southeast Asia in 1850 was under six million acres, by World War I, over 21 million acres were planted to rice, 15 million of which were located in the Chao Phraya, Irrawaddy, and Mekong river deltas. The same period was likewise characterised by dramatic population growth in these three zones of rice cultivation for export, with numbers said to have at least tripled from 1830 to 1910. These trends continued and deepened in subsequent decades. Between the turn of the twentieth century and World War II, the area planted to rice doubled in Lower Burma, the Central Thai Plain, and Cochinchina. Overall, with the onset of primitive accumulation in these three zones of intensive rice cultivation for export, the commodification of land, produce, and labour began to unfold and accelerate, even as demographic pressures started to build up and to bear more and more heavily upon Vietnamese, Burmese, and Thai peasants, as seen in the inexorable fall in average farm size, stagnation or decline in rice yields, and a consequent rise in indebtedness and landlessness over the years. With the successful commodification of land, labour, and produce, 
a 'reserve army' of 'surplus labour' was being conscripted for service (Owen 1971).

Against the backdrop of these common trends, though, important divergences in the contexts, experiences, and consequences of primitive accumulation are also worthy of note. Most obvious in this regard is the distinctiveness of the Chao Phraya River Delta and the Central Thai Plain as a zone of increasingly intensive commercialised rice cultivation. In contrast with the Irrawaddy and Mekong river deltas, this area of settlement and agricultural production was located not in a frontier zone, but within the core realms of the Chakkri dynasty. Unlike Lower Burma and Cochinchina, moreover, the Central Thai Plain saw the accumulation of capital - and land - by immigrant 'Chinese' moneylenders, rice millers, and rice traders who were assimilated into native society rather than segregated and stigmatised as 'foreign'. Relative to the British and French colonial regimes in Burma and Indochina, moreover, the Chakkri dynasty in Siam, restricted as it was by the terms of the Bowring Treaty of 1855, did not impose, enforce, or intensify onerous tax burdens on its peasant population in such ways as to accelerate population growth and expansion of cultivation or to induce ‘agricultural involution' and immiseration among an increasingly indebted and landless class of rural labourers.

Instead, the experience of primitive accumulation among the peasants of the Central Thai Plain was relatively - perhaps even markedly - less disruptive, degrading, and demoralising than it was for their counterparts in Lower Burma and Cochinchina. Thai peasants gradually shifted into production of more and more rice on more and more land for distant markets, while existing structures of authority adapted to this Great Transformation and incorporated a capital-owning class within the ranks of Thai society. In contrast with the hardships - and the rebellions! - of the Depression years in Burma and Vietnam, the 1930s were relatively unremarkable and unthreatening to peasant subsistence and social order alike in rural Thailand, the changes underway in Bangkok notwithstanding. Small wonder: if the land frontiers of the Irrawaddy and Mekong deltas were already closing in the first few decades of the twentieth century, the expansion of rice cultivation continued well into the post-war era in Thailand. ${ }^{2}$

It is against this backdrop of primitive accumulation across the three main river delta zones of Mainland Southeast Asia that we can best understand the distinctiveness of Thailand's trajectory over the course of the past several decades and up to the present. Beyond the much debated 'mixed blessing' of Siam's avoidance of direct colonisation, the distinctive experience of primitive accumulation left important legacies of its own. The modern Thai state and the (Sino-)Thai capitalist class, after all, emerged in the post-war era as inheritors to an

${ }^{2}$ On the Central Thai Plain, see: Ingram 1971; Johnston 1975; Akira Suehrio 1989; Larsson 2007. On Lower Burma, see: Adas 1974. On the Mekong Delta, see: Brocheux 1995; Biggs 2010. 
increasingly dense and productive core zone of settlement and surplus generation in which the relatively slow, easy, gradual process of primitive accumulation, the continuities with pre-capitalist structures of authority, and the assimilation of immigrant comprador capitalists made for the appearance of conservatism, quiescence, and the notable absence of large-scale organisation and mobilisation among the peasantry.

Thus the Central Thai Plain emerged as the economic, cultural, linguistic, and political core of 'Thailand' without the dramatic disruptions, difficulties, and departures experienced by the peasants of Vietnam and Burma. While Communist-led revolution, land reform, and collectivisation proceeded with varying success to 'capture' the increasingly immiserated and proletarianised peasantry of Tonkin, Annam, and Cochinchina, and as land reform, nationalisation, and forced expulsion of the immigrant Indian capitalist class were undertaken in efforts to win control over the peasants of Burma, the 'bureaucratic polity' based in Bangkok proceeded in the 1950s, 1960s, and 1970s to 'liberalise' land laws to eliminate remaining obstacles to land acquisition, sale, and transfer. In the face of Communist victories in Vietnam, Laos, and Cambodia, and mobilisational efforts by the Communist Party of Thailand and left-wing student activists in the 1970s, the response was to reaffirm and reassert the highly conservative premises of the status quo (Bowie 1997).

It was thus in the context of the preceding history of primitive accumulation and the easy defeat and demobilisation of rural activism, especially on the Central Thai Plain, that the parliamentarisation of Thai politics proceeded from the early 1980s onwards (Haberkorn 2011). Left-wing activists were amnestied and easily incorporated into mainstream Thai society (Kanokrat Lertchoosakul 2012), and over time, with few hiccups, power was shifted into the hands of a Parliament whose members overwhelmingly represented rural districts in principle but essentially represented provincial business and Bangkok banking interests in practice (McVey 2000). Stubborn resistance to the parliamentarisation of the 'bureaucratic polity' has been fairly matched - if still not effectively overcome - by the expansion of direct appeals to the rural electorate, not on the basis of land reform or social redistribution, but through the extension of state patronage and subsistence protection to the peasantry. ${ }^{3}$

All in all, the pattern of primitive accumulation across the three main river deltas of Mainland Southeast Asia prefigured important differences in the subsequent political trajectories of Burma, Vietnam, and Thailand. The disruptions and difficulties of primitive accumulation helped to enable and inspire forms of rural mobilisation, peasant revolution, and then nationalisation, land reform, and collectivisation under different kinds of state socialist auspices and experiments in Burma and Vietnam. Meanwhile, a more conservative path to capitalist

${ }^{3}$ On Thaksin Shinawatra's recurring electoral successes, see: McCargo and Ukrist Pathmanand 2004 and Phongpaichit and Baker 2009. 
development and parliamentary democracy was prefigured by the relatively slow and easy form of primitive accumulation in Thailand.

\section{Primitive Accumulation in the Islands: Java, the Malay Peninsula, and the Philippines}

If we turn to the cases of Java, the Malay Peninsula, and the Philippines, moreover, we can see additional evidence of the lasting significance of primitive accumulation across island Southeast Asia. Here perhaps the conservatism of the Thai path to capitalist development and parliamentary democracy is in some ways mirrored in the case of the Malay Peninsula, where primitive accumulation over the nineteenth and early twentieth centuries unfolded with famously 'protective' policies towards the Malay peasantry and heavy reliance on immigrant labour instead. While immigrant Chinese tin miners and, to a lesser extent, Indian rubber plantation labourers provided the basis for large-scale working-class mobilisation unparalleled in Siam and Thailand, the 'protected' Malay peasantry served throughout the twentieth century as a conservative counterpart to the rice farmers of the Central Thai Plain (Kratoska 1982, 1983; Lim Teck Ghee 1977). Actively discouraged from shifting into commercialised agriculture, 'protected' on specially 'reserved' lands, and increasingly governed by state-based interpretations of Islam, the Malay peasantry provided a 'locked-in electorate' for the (reinvented) Malay aristocracy as it restyled itself as UMNO under parliamentary auspices in the 1950s and 1960s, much as Thai peasants provided a ready-made mass base for the chao pho of the 1980s and 1990s. From the 1970s, the New Economic Policy created new, more centralised patronage mechanisms to incorporate this electoral base into a now decidedly business-oriented UMNO machine, arguably in ways foreshadowing the analogous innovations introduced by Thaksin Shinawatra in Thailand at the turn of the twenty-first century.

But if this pattern of primitive accumulation has made Malaysia - for better and for worse - the Thailand of island Southeast Asia, what about the Indonesian and Philippine archipelagos next door? Here the Philippine case suggests itself as a seemingly similar, but in striking ways diverging, pattern of primitive accumulation in comparison with the Central Thai Plain and the Malay Peninsula. In geographical terms, after all, the Philippine archipelago experienced the first waves of primitive accumulation over the latter half of the nineteenth century simultaneously with the river deltas of Mainland Southeast Asia, but with incorporation into the world capitalist economy speeding marketisation in the separate hinterlands of a number of only loosely connected port cities. Alongside Manila with its hinterlands in Central Luzon and the southern Tagalog region, other key entrepôt cities like Cebu and Iloilo served as hubs for the marketisation of land and labour in the Central and Western Visayas in the mid-nineteenth century, with other such ports across areas of Luzon, Bicol, the Visayas, and Mindanao 
emerging over subsequent decades. Thus the pattern of primitive accumulation across the Philippines prefigured an especially ‘uneven' form of development, with the timing, the institutional context, the specific commodity chains, and the consequences destined to differ markedly from one part of the archipelago to the next (McCoy and de Jesus 1982).

Beyond the implications of archipelagic geography, moreover, the Philippine path of primitive accumulation was also distinctive in terms of the institutional auspices under which it unfolded and the implications for capital accumulation, on the one hand, and class relations, on the other. As in Siam, the immigrant 'Chinese' merchants and moneylenders who fanned out from the various port cities of the Philippine archipelago to purchase (and process) agricultural commodities, sell foreign manufactured goods, extend credit, and acquire land were allowed to assimilate into native society, as the children of their unions with native women (indias) were treated as mestizos and freed from the restrictions on their chino fathers. Thus the latter half of the nineteenth century saw the rise to local prominence and, as cabezas de barangay and gobernadorcillos, local elected state office - of Chinese mestizo merchants and landowners. Unlike in Siam, however, the imposition of American rule at the turn of the twentieth century saw not the elaboration of a centralised 'bureaucratic polity' as in Siam and later Thailand, but rather a highly decentralised form of oligarchical democracy, with suffrage expanding from 14 per cent of the population to universal suffrage by Independence in 1946.

Thus as primitive accumulation spread from the established areas of settlement and commercialised agriculture of the late Spanish colonial era to incorporate the full breadth of the Philippine archipelago, it did so under the auspices of a state subordinated to the logic of electoral competition. The consequences were decisive. From the very first years of the twentieth century, capital accumulation unfolded in a context in which state resources and regulatory powers were captured by locally elected mayors, governors, and congressmen, prefiguring a close fusion of political and economic success. Some 92 per cent of the area of the archipelago was designated as public land for lease or sale by the Bureau of Lands in the early decades of the twentieth century; political influence strongly shaped the subsequent auction of the 'friar estates', and the awarding of logging and mining concessions and pasture lease agreements for the decades that followed. Congressional control over the Philippine National Bank (created in 1916) enabled powerful sugar planters to finance the construction of dozens of sugar mills across the country in the 1920s and 1930s and thereby to expand their landholdings considerably in subsequent years. Support for importsubstitution industrialisation in the 1950s and 1960s by the Development Bank of the Philippines likewise allowed entrenched politicians to finance the construction of cement plants and textile factories, even as early post-war protection for the tobacco industry and later quasi-state monopolies and monopsonies for sugar and coconuts intertwined political networks with key agricultural commodity chains across the archipelago. The electoralisation of state power in the 
Philippines as primitive accumulation unfolded not only prefigured 'crony capitalism' on a grand scale as seen in the Marcos era, but also burdened the everyday workings of the market economy with myriad local monopolies and monopsonies, oligopolies and oligopsonies. A study in the 1950s, for instance, revealed that municipal-level restrictions greatly inflated the price of ice in localities across the Philippines, and this example is only the tip of the proverbial iceberg (Hedman and Sidel 2000: 65-87).

At the same time, the intertwining of primitive accumulation with electoral competition for access to state power also decisively shaped class relations in the Philippines throughout the twentieth century and arguably beyond. Primitive accumulation in this form obviously facilitated the emergence and entrenchment of enduring forms of fused local economic and political power, often in dynastic form, in localities across the Philippines (Sidel 1999). However, this kind of localised, electoralised primitive accumulation entailed not only accumulation of land, capital, and access to scarce resources, but also accumulation of control over voters, whether understood as 'clients' or as 'locked-in electorates'. Both accumulation, on the one hand, and dispossession, on the other, have thus been coloured by highly parochial, personal, particularistic, and partisan considerations. Resentment and resistance, and prospects for large-scale mobilisation, in the face of dispossession have thus been inexorably drawn into the logic of electoral competition for access to state power. Small wonder that it was only under the long years of the centralised Marcos dictatorship that the threat of peasant revolution could be credibly mounted across the diverse terrain of the Philippine archipelago, and even then with great unevenness across different regions and crop zones as well.

Thus overall, the Philippines' electoralised form of primitive accumulation has in various ways complicated, compromised, and constrained capitalist development in the country, diminishing the dynamism of its market economy and deepening economic and social inequalities beyond those observed elsewhere in the region. This form of primitive accumulation has likewise condemned the Philippines to a decidedly oligarchical form of democracy, with counter-hegemonic challenges to the status quo surfacing in a cyclical pattern of crises and 'transformist' re-equilibration, what Gramsci called a 'passive revolution' in which pressures for change are effectively sublimated and suppressed. Hence the far less rosy picture of capitalist development in the Philippines as compared with Thailand (Hedman 2006).

Finally, if we turn to the pattern of primitive accumulation which crystallised on Java and parts of Sumatra over the nineteenth century, we find an especially complex set of distinctive and significant legacies still haunting Indonesia today. Here, three distinctive features of primitive accumulation in the Indonesian archipelago are especially worthy of note. First of all, as is well known, the commodification of land and labour on Java and elsewhere unfolded in considerable measure through forms of market mediation largely controlled by immigrant 
merchants whose 'Chinese' ancestry served as the basis for segregation and stigmatisation as 'foreign', in contrast with the processes of assimilation and integration observed in Siam and the Philippines. As the Javanese aristocracy - and its 'native' counterparts elsewhere in the archipelago - remained at one arm's length from the workings of the market, capital accumulation thus remained problematically 'foreign' in ways virtually unparalleled elsewhere in Southeast Asia (Rush 1990).

Secondly, more than any other colony in Southeast Asia, the administration of the Dutch East Indies depended heavily on the strengthening of village institutions, which were understood by Dutch officials to have enjoyed considerable 'traditional' depth and strength, and were consequently relied upon, reinforced, and reinvented as the bases for political control and economic extraction (Breman 1980). Over the course of the late nineteenth and early twentieth centuries, moreover, Dutch colonial scholars of 'customary' or adat law, most notably those coming out of the adatrecht school in Leiden, began to systematise adat law and reify adat institutions, so that through the 'invention of tradition' a desa adat or customary village emerged as a supposedly "autonomous, corporate village community - the ideal-type dorpsrepubliek” (Warren 1993: 3). Thus revisionist scholars have concluded that "the village as a corporate, autonomous and territorially defined unit was in a certain sense a creation of intensified colonial rule in the early nineteenth century" (Elson 1994: 29).

The strength of community boundaries created by Dutch administrative policies was further enhanced by colonial reliance on the village as the essential unit for economic extraction, most notably in the clove monopoly in the Moluccas and under the Cultivation System of forced extractions of sugar, coffee, and other cash crops in Java. While some pre-colonial villages had strongly established patterns of communal land tenure and labour-sharing schemes (see for example, Elson 1986), colonial-era villages in the Dutch East Indies more widely and insistently relied on communal cultivation of various export crops and the rotation and apportionment of land and labour at the village level (Elson 1994: 49-67). Significantly, moreover, the colonial regime erected considerable barriers to the alienation of land to non-villagers and left considerable landholdings in the realm of village control, whether in the form of communal lands or the salary lands (tanah bengkok) awarded to village officials (Burns 1989: 17-37). In short, if the essential dimensions of community strength are "the mechanisms of authoritative control and jurisdiction of membership, the channels of discursive focus that establish a folklore of place, and the forms of economic cooperation that underpin membership claims to local subsistence" (Magagna 1991: 19), then certainly Dutch policies created strong notions of community when compared to colonial-era villages elsewhere in Southeast Asia. Small wonder that beyond Sinicized Annam and Tonkin, only village Java has been designated by anthropologists hyperbolically - as characterised by so-called 'closed corporate communities' (see for example, Wolf 1957). 
Thus, in the Dutch East Indies, primitive accumulation unfolded under distinctly 'communitarian' auspices. Nowhere was this more true than in Java, where the state-run Cultivation System of the mid-nineteenth century forced the peasantry into a complex web of relations of production unparalleled in their intensity in Southeast Asia at the time. The Cultivation System awarded collective ownership of land to villages and assigned villagers collective responsibility for payment of land taxes (landrente). These obligations, as well as restrictions on mobility, tied Javanese peasants to their villages, which "were reorganized both to emphasize the uniform obligation of all village members and to facilitate supervision" (Cribb 2000: 137). After the passage of the Agrarian Law of 1870, and with the dawning of the Ethical Policy in the early 1900s, this pattern was preserved through contracts between Javanese villages and European estates; here a longer passage from Geertz is illustrative:

"Not only did the estate have to adapt to the village through the landlease system and various other 'native-protection' devices forced on it by an 'ethical' colonial government, but, even more comprehensively, the village had to adapt to the estate. The mode of its adaptation was again involutional. The basic pattern of village life was maintained, and in some ways even strengthened, and the adjustment to the impingements of high capitalism effected through the complication of established institutions and practices. In land tenure, in crop regime, in work organization, and in less directly economic aspects of social structure as well, the village...faced the problems posed by a rising population, increased monetization, greater dependence on the market, mass labor organization, more intimate contact with bureaucratic government, and the like, not by a dissolution of the traditional pattern into an individualistic 'rural proletarian' anomie, nor yet by a metamorphosis of it into a modern commercial farming community. Rather...it maintained the over-all outlines of that pattern while driving the elements of which it was composed to ever-higher degrees of ornate elaboration and Gothic intricacy. Unable either to stabilize the equilibrated wetrice system it had autochthonously achieved before 1830, or yet to achieve a modern form on, say, the Japanese model, the twentiethcentury lowland Javanese village - a great sprawling community of desperately marginal agriculturalists, petty traders, and day laborers - can perhaps only be referred to, rather lamely, as "post-traditional." (Geertz 1963: 89)

Third and finally, primitive accumulation in the Indonesian archipelago unfolded in ways which forced an unusually early proletarianisation of the peasantry, especially on Java. The deepening incorporation of the Indonesian archipelago within the world economy over the course of the nineteenth century entailed advanced forms of exploitation in commercial agriculture, commodity 
processing, and natural resource exploitation, as well as the elaboration of a modern transportation network, creating a sizeable class of wage labourers. By 1900, some 435,000 hectares were leased out to large private estates on Java (Booth 1998: 30), and connected through sugar mills and railroads to port cities like Batavia, Semarang, and Surabaya, which hosted more than 150,000 residents by the turn of the twentieth century (Dick 2002a: 261, 253).

"By 1900 Java was the most technologically modern and integrated economy between Bengal and Japan. The technology of the Industrial Revolution had been applied to a network of transport and communications, to an export-oriented sugar milling industry with giant factories commanding most of the best land on the island, to irrigation systems, to ancillary metal-working and heavy engineering industries, to the production of some urban middle-class consumer goods such as bread, soft drinks and ice, to construction materials such as bricks and timber to public utilities such as gas and power. Excluding the tiny urban islands of Singapore and Penang, there was nowhere else like it in Southeast Asia." (Dick 2002b: 17-18)

The construction of a modern infrastructure for intensive export-oriented agricultural production continued apace well into the twentieth century. By 1942 , there were 1.3 million hectares of irrigated rice fields, thousands of kilometres of asphalted, and metalled roads, and 5,500 kilometres of railway line on Java (Ravesteijn and Nispen 2007: 274; see also Ravesteijn and Kop 2008).

From the mid-nineteenth century forward, a similarly modern infrastructure was extended to various parts of the other islands of the Indonesian archipelago. By 1900, some 370,000 hectares of land outside Java were held by private estates, with nearly another plus another 480,000 under various kinds of concessions; by the 1920s, there were 500,000 hectares under concession in North Sumatra alone, with private estates across the entirety of the archipelago claiming nearly three million hectares of land (Booth 1998: 30, 299). Enclaves of concentrated, and heavily capitalised, production dotted the landscape: a vast plantation belt along the eastern coast of Sumatra, tin mines on the islands of Bangka and Belitung, coal mines in West Sumatra, oil refineries in Borneo, and scattered mines and plantations elsewhere. Most notable was the so-called 'Deli belt' of plantations on the eastern coast of Sumatra:

"By 1930 more than 11,000 Europeans were living on the East Coast, directly or indirectly involved in the estate industry. For the first time, personnel, capital, sites of production, and processing plants drawn from, or situated in, different parts of the Western and colonized worlds were pulled together under single, but notably distinct, corporate structures.” (Stoler 1985: 19) 
Overall, compared to the Philippines and much of the rest of Southeast Asia at the turn of the twentieth century, the Dutch East Indies was distinguished by the relatively early emergence of a class of wage labourers concentrated in large-scale agricultural production and processing and key nodes of modern transport. By 1930, an estimated 300,000 coolie labourers were toiling on the plantations of East Sumatra, and nearly 250,000 more were to be found working on large plantations and mines elsewhere in the Outer Islands (Lindblad 1999: 101). On Java, sizeable concentrations of labourers were likewise to be found, and not only on the plantations: historians have estimated that industrial workers numbered nearly 250,000 by 1942 , with an additional 50,000 labouring on the railways, and many thousands more in the harbours of Batavia, Semarang, and Surabaya, and on the steamboats plying inter-island and international routes from these ports (Ingleson 1986a, 1986b).

These distinctive features of primitive accumulation as it unfolded in the Dutch East Indies have had enduring consequences for capitalist development and political change in Indonesia. Aside from Tonkin, with its own history of agricultural involution, immiseration, and early 'export' of proletarianised peasant labour (Gourou 1955), nowhere else in Southeast Asia has seen such a history of collective action, mass mobilisation, and popular radicalism as that witnessed on Java and in other areas of the Indonesian archipelago. In the Sarekat Islam of the 1910s and early 1920s, Southeast Asia saw its first large-scale mass popular movement, unparalleled in extent elsewhere in the region, and in the Partai Komunis Indonesia, we likewise find the first Communist Party in Asia (Takashi Shiraishi 1990). In the Revolusi of the early post-war era, we can observe a struggle for independence notable for the intensity and diversity of autonomous local popular mobilisation, including many local 'social revolutions' across areas of Java and Sumatra, and in the early aftermath of Independence, we see political parties more diverse and collectivist in their identities and forms of voter mobilisation than found anywhere else in Southeast Asia (Kahin 1985).

Against this backdrop, capitalist development and political order in Indonesia have assumed distinctive forms. It was only through considerable state violence that demobilisation of the popular classes could be effected by the Suharto regime, and it was against the abiding threat of popular mobilisation that a very elaborately and intensively institutionalised form of authoritarian rule was constructed across the full breadth of the Indonesian archipelago. Even as the Indonesian economy moved through import-substitution industrialisation under an oil boom into export-oriented industrialisation, moreover, it retained important features of capital accumulation and class relations from the colonial era of primitive accumulation. The 'foreign' ancestry of the dominant segment of the capitalist class in the archipelago remained problematic, enabling and impelling a succession of experiments with economic 'nationalism' and encouraging forms of state intervention and ownership stubbornly resistant to pressures for economic liberalisation, deregulation, and privatisation (Shin 1989). Even as 
Indonesia shifted from centralised authoritarian rule to decentralised democracy at the turn of the twenty-first century, these legacies continued to shape the patterns of capitalist development and political change across the archipelago in a variety of ways.

\section{Conclusions: James C. Scott and Comparative Analysis of Primitive Accumulation}

As this article has put forward, a comparative analysis of primitive accumulation provides a potentially illuminating vantage point from which to understand - and to explain - key patterns of divergence in the trajectories of Southeast Asian countries, both in terms of capitalist development and political change. The preceding analysis has remained largely suggestive and limited in detail with regard to the tracing of causal linkages, and thus remains vulnerable to charges of superficiality and oversimplification. But at the very least, this essay has offered a set of new arguments with regard to the significance of otherwise neglected agrarian determinants of the modern economic and political trajectories of Southeast Asia into the twenty-first century. It is to be hoped that further consideration of these arguments will be undertaken in due course.

At the same time, it is perhaps worth noting that the possibilities for this kind of comparative historical sociology of agrarian change in Southeast Asia were first identified but then abandoned by James C. Scott himself, as seen in the final chapter of The Moral Economy of the Peasant in 1976. For this we must remain grateful, as it has only been through his emancipation from the iron cage of 'the comparative method' that Scott has gone on to produce such powerfully original and illuminating contributions to our understandings of politics in Southeast Asia and far beyond. The exercise in comparative analysis provided above can thus only provide a very feeble tribute to Scott's work, and a highly derivative kind of argument for the continuing importance of aspects of politics which Scott has done more than any other scholar to illuminate over the years. But perhaps at least it does so in ways which might speak with emphasis if not originality to a wide range of scholars interested in the contemporary politics of Southeast Asia.

\section{References}

Adas, Michael. 1974. The Burma Delta: Economic Development and Social Change on an Asian Rice Frontier, 1852-1941. Madison: University of Wisconsin Press.

Aston, T.H. and Philpin, Charles H.E. (eds.). 1985. The Brenner Debate: Agrarian Structure and Economic Development in Pre-Industrial Europe. Cambridge: Cambridge University Press.

Akira, Suehrio. 1989. Capital Accumulation in Thailand 1955-1985. Tokyo: Centre for East Asian Cultural Studies. 
Biggs, David. 2010. Quagmire: Nation-Building and Nature in the Mekong Delta. Seattle: University of Washington Press.

Booth, Anne. 1998. The Indonesian Economy in the Nineteenth and Twentieth Centuries: A History of Missed Opportunities. Basingstoke: Macmillan.

Bowie, Katherine A. 1997. Rituals of National Loyalty: An Anthropology of the State and the Village Scout Movement in Thailand. New York: Columbia University Press.

Breman, Jan. 1980. The Village on Java and the Early-Colonial State. Rotterdam: Comparative Asian Studies Programme, Erasmus University.

Brocheux, Pierre. 1995. The Mekong Delta: Ecology, Economy, and Revolution, 18601960. Madison: University of Wisconsin Center for Southeast Asian Studies.

Burns, Peter. 1989. The myth of Adat. Journal of Legal Pluralism 28, 1-127.

Cribb, Robert. 2000. Historical Atlas of Indonesia. Richmond: Curzon Press.

Dick, Howard. 2002a. Surabaya, City of Work: A Socioeconomic History, 1900-2000. Athens: Ohio University Center for International Studies.

Dick, Howard. 2002b. State, nation-state and national economy. In Howard Dick, Vincent J.H. Houben, J. Thomas Lindblad, and Thee Kian Wie (eds.), The Emergence of a National Economy: An Economic History of Indonesia, 1800-2000, pp. 9-34. Honolulu: University of Hawai’i Press.

Elson, E. Robert. 1994. Village Java under the Cultivation System, 1830-1870. Sydney: Allen and Unwin.

Elson, E. Robert. 1986. Aspects of peasant life in early $19^{\text {th }}$ century Java. In David P. Chandler and M.C. Ricklefs (eds.), Nineteenth and Twentieth Century Indonesia: Essays in Honour of Professor J.D. Legge, pp. 71. Clayton: Monash University Centre of Southeast Asian Studies.

Foucault, Michel. 1977. Discipline and Punish: The Birth of the Prison. New York: Vintage.

Furnivall, John F. 1939. The fashioning of leviathan: the beginnings of British rule in Burma. Journal of the Burma Research Society 29(1), 3-137.

Furnivall, John F. 1948. Colonial Policy and Practice: A Comparative Study of Burma and Netherlands India. Cambridge: Cambridge University Press.

Geertz, Clifford. 1963. Agricultural Involution: The Processes of Ecological Change in Indonesia. Berkeley: University of California Press.

Gourou, Pierre. 1955. Les Paysans du Delta Tonkinois: Étude de Géographie Humaine. Paris: Mouton.

Haberkorn, Tyrell. 2011. Revolution Interrupted: Farmers, Students, Law and Violence in Northern Thailand. Madison: University of Wisconsin Press.

Ingram, C. James. 1971. Economic Change in Thailand 1850-1970. Stanford: Stanford University Press.

Moore, Barrington, Jr. 1966. Social Origins of Dictatorship and Democracy: Lord and Peasant in the Making of the Modern World. Boston: Beacon Press.

Hedman, Eva-Lotta. 2001. Contesting state and civil society: Southeast Asian trajectories. Modern Asian Studies 35(4), 921-951.

Hedman, Eva-Lotta. 2006. In the Name of Civil Society: From Election-Watch Movements to People Power in the Philippines. Honolulu: University of Hawai'i Press.

Hedman, Eva-Lotta and Sidel, John T. 2000. Philippine Politics and Society in the Twentieth Century: Colonial Legacies, Post-Colonial Trajectories. London: Routledge.

Ingleson, John. 1983. Life and work in colonial cities: harbour workers in Java in the 1910s and 1920s. Modern Asian Studies 17(3), 455-476.

Ingleson, John. 1986. In Search of Justice: Workers and Unions in Colonial Java, 19081926. Singapore: Oxford University Press. 
Johnston, David B. 1975. Rural Society and the Rice Economy in Thailand, 1880-1930.

(Unpublished doctoral thesis). Yale University.

Kahin, Audrey R. (ed.). 1985. Regional Dynamics of the Indonesian Revolution: Unity from Diversity. Honolulu: University of Hawai’i Press.

Kanokrat, Lertchoosakul. 2012. The Rise of the Octobrists: Power and Conflict Among Former Left-Wing Student Activists in Contemporary Thai Politics. PhD Thesis, London School of Economics and Political Science.

Kratoska, Paul H. 1982. Rice cultivation and the ethnic division of labor in British Malay. Comparative Studies in Society and History 24(2), 280-314.

Kratoska, Paul H. 1983. 'Ends that we cannot foresee': Malay reservations in British Malaya. Journal of Southeast Asian Studies 14(1), 149-168.

Larsson, Tomas Henrik. 2007. Capitalizing Thailand: Colonialism, Communism, and the Political economy of Rural Land Rights. (Unpublished doctoral thesis). Cornell University.

Lieberman, Victor. 2003. Strange Parallels: Southeast Asia in Global Context, c. 800 - 1830: Volume 1: Integration on the Mainland. Cambridge: Cambridge University Press.

Lindblad, Thomas J. 1999. New destinations: conditions of coolie labour outside East Sumatra, 1910-1938. In Vincent, J.H. Houben and J. Thomas, Lindblad (eds.), Coolie Labour in Colonial Indonesia: A Study of Labour Relations in the Outer Island, c. 1900-1940, pp. 79-108. Wiesbaden: Harrassowitz Verlag.

Lim Teck Ghee. 1977. Peasants and Their Agricultural Economy in Colonial Malaya 1874-1941. Kuala Lumpur: Oxford University Press.

Magagna, Victor V. 1991. Communities of Grain: Rural Rebellion in Comparative Perspective. Ithaca: Cornell University Press.

Mahoney, James. 2001. Legacies of Liberalism: Path Dependency and Political Regimes in Central America. Baltimore: Johns Hopkins University Press.

Marx, Karl. 1977. Capital, Volume 1. New York: Vintage.

McCargo, Duncan and Ukrist Pathmanand. 2004. The Thaksinization of Thailand. Copenhagen: Nordic Institute of Asian Studies.

McCoy, Alfred W. and Edilberto C. de Jesus. (eds.). 1982. Philippine Social History: Global Trade and Local Transformations. Quezon City: Ateneo de Manila University Press.

McVey, Ruth. (ed.). 2000. Money and Power in Provincial Thailand. Copenhagen: Nordic Institute of Asian Studies.

Owen, Norman G. 1971. The rice industry of mainland Southeast Asia 1850-1914. Journal of the Siam Society 59(2), 75-143.

Paige, Jeffery M. 1997. Coffee and Power: Revolution and the Rise of Democracy in Central America. Cambridge, MA: Harvard University Press.

Phongpaichit, Pasuk and Baker, Chris. 2009. Thaksin (2nd Revised Edition). Seattle: University of Washington Press.

Ravesteijn, Wim and Marie-Louise ten Horn-van Nispen. 2007. Engineering an empire: the creation of infrastructural systems in the Netherlands East Indies 1800-1950. Indonesia and the Malay World 35(103), 273-292.

Ravesteijn, Wim and Kop, Jan (eds.). 2008. For Profit and Prosperity: The Contribution made by Dutch Engineers to Public Works in Indonesia 1800-2000. Leiden: KITLV Press.

Rush, James R. 1990. Opium to Java: Revenue Farming and Chinese Enterprise in Colonial Indonesia, 1860-1910. Ithaca: Cornell University Press.

Scott, James C. 1976. The Moral Economy of the Peasant: Rebellion and Subsistence in Southeast Asia. New Haven: Yale University Press.

Sidel, John T. 1999. Capital, Coercion, and Crime: Bossism in the Philippines. Stanford: Stanford University Press. 
Sidel, John T. 2008. Social origins of dictatorship and democracy revisited: colonial state and Chinese immigrant in the making of modern Southeast Asia. Comparative Politics 40(2), 127-147.

Sidel, John T. 2012. The fate of nationalism in the new states: Southeast Asia in comparative historical perspective. Comparative Studies in Society and History 54(1), 114-144.

Shin Yoon Hwan. 1989. Demystifying the Capitalist State: Political Patronage, Bureaucratic Interests, and Capitalists-In-Formation in Soeharto's Indonesia. (Unpublished doctoral thesis). Yale University.

Stoler, Ann Laura. 1985. Capitalism and Confrontation in Sumatra's Plantation Belt, 1870-1979. New Haven: Yale University Press.

Takashi Shiraishi, 1990. An Age in Motion: Popular Radicalism in Java, 1912-1916. Ithaca: Cornell University Press.

Warren, Carol. 1993. Adat and Dinas: Balinese Communities in the Indonesian State. Kuala Lumpur: Oxford University Press.

Wolf, Eric R. 1957. Closed corporate peasant communities in Mesoamerica and Central Java. Southwestern Journal of Anthropology 13(1), 1-18. 